\title{
A NEW TWIST.IN VOIDING THE ATTACHMENT OF CORPORATE STOCK
}
A
unioue case has been decided in Delaware ${ }^{1}$ which should serve as a warning to all states which have neither section I3 of the Uniform Stock Transfer Act ${ }^{2}$ nor a statutory provision preventing mergers at least to the extent of stockholders' shares which have been validly at- tached. ${ }^{3}$ In Union Chemical Eo Materials Corporation v. Cannon, the plaintiffs had instituted a stockholders' derivative suit against certain defendant shareholders on behalf of Union Chemical \& Materials, a Delaware corporation. Jurisdiction was obtained over the defendants when their shares of Union stock, the certificates of which were all lo- cated outside Delaware, were validly seized under the Delaware sequestration statute. ${ }^{\sigma}$ Shortly thereafter, Union merged, under the pro- visions of the Delaware merger statutes, ${ }^{6}$ with Vulcan Materials Com- pany, a New Jersey corporation.
When the defendants subsequently moved for dismissal, the Court of Chancery denied the plea, holding that the merger had not deprived Delaware of jurisdiction." The Supreune Court of Delaware unani- mously reversed on the grounds that the lower Delaware court had never obtained personal jurisdiction and that since the seized shares were those of a now nonexistent corporation, no property of the de- fendants remained over which the power of the court could be exercised. ${ }^{8}$

\footnotetext{
${ }^{1}$ Union Chem. \& Materials Corp. v. Cannon, 148 A.2d 348 (Del. 1959).

${ }^{3}$ See note 23 infra.

${ }^{8}$ Jurisdictions in this unenviable position which also do not allow seizure by means other than attachment of shares are: Colorado, Florida, Georgia, Hawaii, Nebraska, and Oklahoma. New Hampshire would also be in this position, but its merger statute provides that, "[T] he corporations whose charters are so repealed shall continue as bodies corporate for the term of three years for the purpose of concluding such consolidation or inerger and of closing and settling their concerns and for no other purpose, but subject to the jurisdiction of the superior court to revive such corporations if justice so requires for special purposes." N.H. REv. STAT. ANN. § 294:42 (1955). This language may be broad enough to prevent the attached shares from being converted.

'DEI. CODE ANN. tit. 8, \$ 169 (1953).

DEL. CODE ANN. tit. I0, \$. 366 (1953).

- Del. Code ANN. tit. 8, \$252 (1953).

'Cannon v. Union Chem. \& Materials Corp., - Del. -, 144 A.2d 142 (Del. Ch. 1958).

Union Chem. \& Materials Corp. v. Cannon, supra note 1, at 352.
} 
The Chancellor found a basis for the maintenance of jurisdiction in section 259(a) of the Delaware Code which provides, with regard to mergers, that all rights of creditors and all liens upon any property of any of the constituent corporations shall be preserved unimpaired, shall attach to the surviving corporation, and may be enforced against it. ${ }^{9}$ In this statutory provision the Chancellor "discovered" a duty on Vulcan to preserve the seizure. ${ }^{10}$ The Supreme Court of Delaware, on the other hand, construed the statute to limit the surviving corporation's liability to liens upon any corporate property of the constituent corporations. ${ }^{11}$ Since a corporation is deemed to have no property interest in the shares of its stockholders, ${ }^{12}$ section 259 (a) was thus properly declared inapplicable in this case.

Nor was the Delaware sequestration scheme, which voids any transfer or assignment of seized property, ${ }^{13}$ of assistance to the plaintiffs here; for a merger conventionally is held to cause the conversion ${ }^{14}$ of shares rather than their transfer or assignment.

Perhaps the basic thrust of the plaimtiffs' argument relied on the broad principle that jurisdiction once acquired is not defeated by subsequent events. ${ }^{15}$ As noted by the Delaware appellate court, however, this seeming axiom is apparently derived from cases where personal as well in rem jurisdiction has been gained. ${ }^{16}$ Here personal jurisdiction over the defendants was never acquired by the sequestration of their shares. The merger, being valid under Delaware statutes, lawfully and automatically converted the situs of the Union stock. from Delaware to Vulcan in New Jersey, ${ }^{17}$ thereby depriving the Delaware court of the

B "[B] at all rights of creditor's and all liens upon any property of any of said constituent corporations shall be preserved unimpaired, and all debts, liabilities and duties of the respective constituent corporations shall thenceforth attach to said resulting or surviving corporation, and may be enforced against it to the same extent as if said debts, liabilities and duties had been incurred or contracted by it." . DEL. CODE ANN. tit. $8, \S 259$ (1953).

${ }^{10}$ Union Chem. \& Materials Corp. v. Cannon, supra note I, at 3521 .

${ }^{11}$ Ibid.

${ }^{12}$ Hine, Situs of Shares Issued Under the Uniform Stock Transfer Act, 87 U. PA. L. REv. 700, 704 (1939). See also Rhode Island Hospital Trust Co. v. Doughton, 270 U.S. 69,81 (1926) (the owner of the shares of stock in a company is not the owner of the company's property).

13 "Any transfer or assignment of the property so seized after the seizure thereof shall be void. ..." DEL. CODE ANN. tit. ro, \$366(c) (1955).

If Union Chem. \& Materials Corp. v. Cannon, supra note $r$, at 352 .

${ }^{16} 21$ C.J.S: Courts $\$ 93$ (1955).

30 Union-Chem. \& Materials Corp. v: Cannon, supra note $x$, at 352

${ }^{17} \mathrm{New}$ Jersey has incorporated section ${ }_{3} 3$ of the Uniform Stock Transfer Act into 
ress by which it claimed jurisdictional power ${ }^{18}$ and through which, subsequently, it could enforce a money judgment. ${ }^{19}$

Arguably, of course, the conversion inured to the benefit of the Delaware sequestrator upon a theory that under Delaware law, ${ }^{20}$ at least, he held the equitable interest in the Union shares at the time of the merger. This was, perhaps, the essence of the Chancellor's holding. The trouble with this view, regardless of whatever theoretical and logical validity it may have, is that it fails to anticipate the legal and practical difficulties which would attend its applicaton. For instance, even if Delaware were willing to claim jurisdiction on such a basis, give the plaintiffs a money judgment on the merits, and order a sale of the Union shares, such a judgment or order would eventually have to be enforced through Vulcan in New Jersey, at least so long as Delaware's jurisdiction over surviving corporations is statutorily limited to matters involving corporate property. In a New Jersey enforcement action, the Delaware judgment or order would almost certainly be met with a successful collateral attack upon the jurisdictional issue since the state of incorporation, New Jersey in Vulcan's case, normally is held to exercise sole jurisdiction over the issuance and transfer of shares of its corporations. ${ }^{21}$ Indeed, by the very fact that Delaware allows its corporations to merge with foreign corporations, it may be said to recognize specifically that, with regard to the conversion of shares, the law of the foreign state is to govern once the merger is complete. Therefore, it would seem that New Jersey could properly refuse to give full faith and credit to the Delaware judgment or order.

No matter how legally correct the decision, it obviously reaches a bad result. The plaintiffs did everything within their power under the sequestration statutes to obtain jurisdiction, ${ }^{22}$ only to see it lost through the subsequent actions of the defendants. Yet any other decision would require, as noted, an unwarranted stretching of the statutes or a course which would prove futile in its ultimate effect. Of course, this particu-

its statutes. Therefore, the situs would be the place where the certificates are located. Elgart v. Mintz. 124 N.J. Eg. 136, 200 Atl. 488 (1938).

$\ldots 18$ Would the Delaware courts have lost jurisdiction if Union had merged with another Delaware corporation? The same reasoning which was applied in this case to cause the jurisdiction to be lost would be applicable in the hypothetical situation. But see. Cannon v. Union Chem. \& Materials Corp., supra note 72 at 144 .

${ }^{10}$ Supra note 5.

"Ibid.

$n 1$ "Shares in a corporation are subject to the jurisdiction of the state in which the corporation was incorporated." RESTATEMENT, CoNfLict of LAWs § 53(r) (1934). : : Supra note 5 . 
lar case would never arise in those states which have adopted section 13 of the Uniform Stock Transfer Act, which makes the situs of shares, for attachment purposes, the place where the representative stock certificates are located. ${ }^{23}$ In such states attached certificates, being tangible in nature, could not normally be converted against the interests of the court so long as the court held them. ${ }^{24}$ However, assuming the continued validity of whatever considerations have influenced a number of states to reject section $I_{3}$ and to authorize attachment only through sequestration of the intangible shares, ${ }^{25}$ even these states could prevent the result of the instant case by incorporating within their merger schemes a clause voiding the conversion of attached shares and retaining jurisdiction over the surviving corporation to enforce such a law. Such a provision would permit a merger to the extent of unsequestered shares, thereby avoiding undue prejudice in those situations where a great majority of the stock of a corporation is not involved in a lawsuit. If such a statutory device had existed in the present case, Vulcan, having notice of the attachment, would have been bound to honor it and would have had the duty to exchange Vulcan shares for attached Union shares only when and in the manner directed by the Delaware Court. It was an enactment of this sort which the Delaware Supreme Court invited its legislature to adopt in order to prevent the repetition of the undesirable result reached in the Cannon case. ${ }^{26}$

Thus, even if it serves no other good purpose, the instant decision should act as a stimulant to the legislatures of Delaware and other similarly situated states to enact legislation effective to close this loophole in their attachment proceedings.

${ }^{23}$ "No attachment or levy upon shares of stock for which a certificate is outstanding shall be valid until such certificate be actually seized by the officer making the attachment or levy, or be surrendered to the corporation which issued it, or its transfer by the holder be enjoined. Except where a certificate is lost or destroyed, such corporation shall not be compelled to issue a new certificate for the stock until the old certificate is surrendered to it." UNIFORM STOCK TRANSFER AcT $\S$ I3 $_{3} ; 6$ U.L.A. $\S$ r $_{3}$ (1922). See also note 17 supra.

24 32 COLUM. L. Rev. 894, 897 (1932).

${ }^{25}$ Supra note 3 .

${ }^{26}$ "The situation, in our opinion, stems from the failure of our merger statutes to provide, in cases of attachment of stock, for a deferment of the effective date of the conversion of any shares held under valid attachment until the attachment shall have been dissolved or otherwise disposed of, thus preserving the situs of the attached shares in this state." Union Chem. \& Materials Corp. v: Cannon, supra note I, at $35 \mathrm{I}$. 